Başvuru Tarihi: 08.11.2017 Received Date: 08.11.2017

Yayına Kabul Tarihi: 04.01.2018 Accepted Date: 04.01.2018

Yayınlanma Tarihi: 29.01.2018 Published Date: 29.01.2018
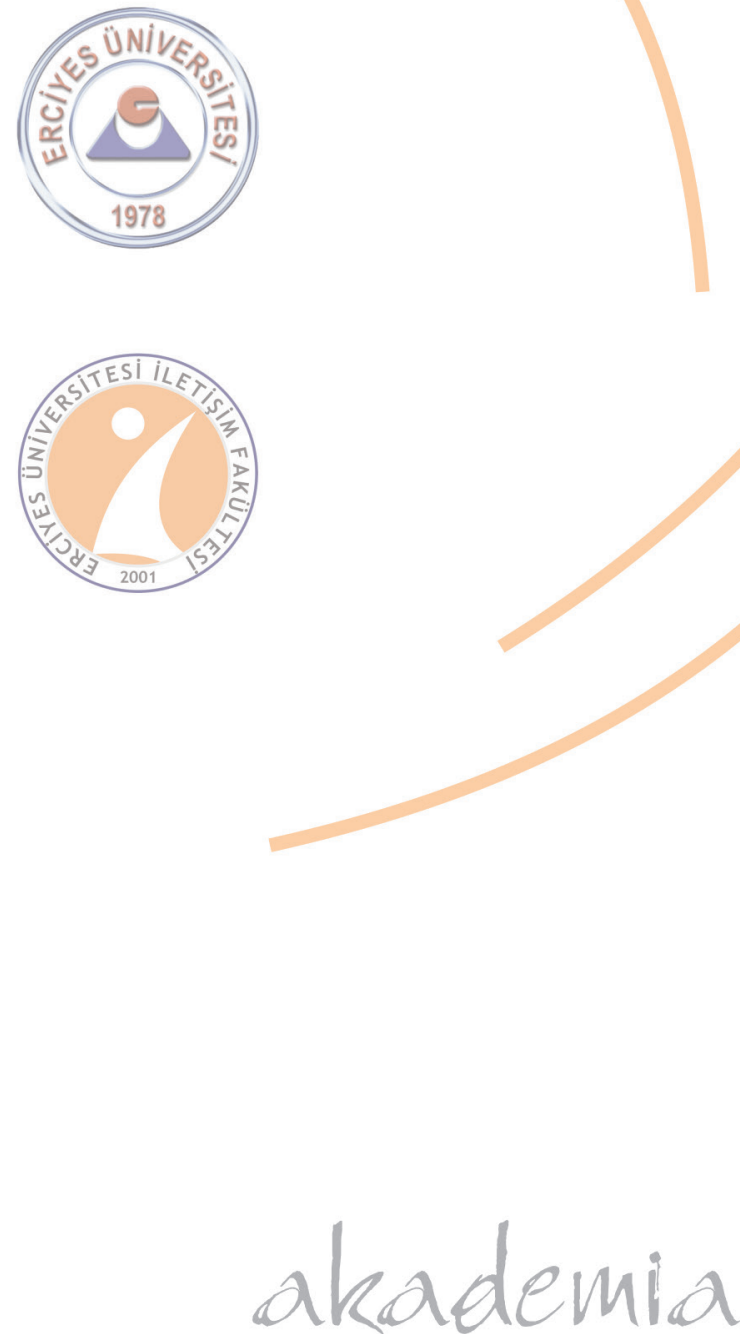
ISSN:1308-3198

Erciyes İletişim Dergisi akademia 2018

Cilt (Volume): 5, Say1 (Number): 3, (216-236)
Serdar SEVER (Prof. Dr.)

Anadolu Üni. İletişim Bilimleri Fakültesi

nssever@anadolu.edu.tr

Adil BİCAL (Arş. Gör.)

Anadolu Üni. İletișim Bilimleri Fakültesi

abical@anadolu.edu.tr

\section{OYUNLAŞTIRMADA OYUN ELEMANLARININ KULLANIMI: ADIDAS MICOACH, KHAN ACADEMY, SUPERBETTER VE SWARM UYGULAMALARININ ÖRNEK OLAY YÖNTEMİ ILEE INCELENMESI ${ }^{1}$}

\section{$\ddot{O} z$}

$\mathrm{Bu}$ çalışma, oyun elemanlarının oyunlaştırmada kullanımına odaklanmaktadır. Oyunlaştırma, oyun tasarım unsurları (elemanları) ve esaslarının gerçek dünyaya ve oyun olmayan içeriğe aktarılmasıdır. Bu açıdan oyun elemanları oyunlaştırmanın temelini teşkil etmektedir. Oyun literatüründe oyun sistemini meydana getiren parçalar olarak ifade edilen oyun elemanları ile ilgili çok az ampirik çalışma bulunmaktadır. Oyunlaştırmaya dönük çalışmalar ise, daha başlangıç aşamasında olup, bu konuda kurumsal bir çerçevenin eksikliği hissedilmektedir. $\mathrm{Bu}$ doğrultuda bu çalışmada oyun elemanlarının oyunlaştırmada kullanımı dört örnek olay üzerinden incelenerek; oyun elemanlarının varlığı, birbirleri ile etkileşimi ve uygulamalarda kullanım biçimleri incelenmiştir. Çalışmada öncelikle oyun elemanlarının neler olduğu, literatür araştırmasında ortaya koyulmuş ve araştırma bölümünde elde edilen bilgiler ile geliştirilmiştir. Konuyu derinlemesine inceleme imkanı verdiği için çalışmada nitel örnek olay incelemesi yöntemi tercih edilmiştir. Uygulamalar arasında karşılaştırma yapabilme imkanı tanıdığı için dört farklı kategoride oyunlaştırma uygulaması araştırmaya dahil edilmiştir. Araştırma sonunda elde edilen bulgular çerçevesinde dört uygulamada da birçok oyun elemanının bulunduğu ancak gözlemlenen oyun elemanlarının tüm uygulamalarda aynı oranda kullanılmadığı, bazılarının daha çok öne çıtığı görülmüştür. Bunun yanı sıra oyun elemanlarının birbirleri ile ilişkili biçimde işlediği ve oyunlaştırmayı birç̧ok parçadan oluşan bir bütün olarak yansıttıkları tespit edilmiştir.

Anahtar Kelimeler: Oyunlaştırma, Oyun Elemanları, Oyun Mekanikleri.

\section{USE OF GAME ELEMENTS IN GAMIFICATION: A CASE STUDY ON ADIDAS MICOACH, KHAN ACADEMY, SUPERBETTER AND SWARM APPLICATIONS}

\section{Abstract}

This study focuses on use of game elements in gamification. Gamification is the transfer of game design elements and essentials, which form the basis of gamification, into real world and non-game content. Literature is limited to a few empirical studies that handle the composing elements of a game system. Gamification-related studies are still at their early stages and there is lack of research on theoretical framing of the subject matter. To fill the gap in literature, based on four case studies, this study examines the use of game elements in gamification in terms of their presence, interactions and types of use in applications. Study initially manifests game elements in literature review and later this manifestation is developed through acquired knowledge during research. We preferred qualitative case study method that enables to examine the subject in detail. We added gamification applications in four different categories for comparison purpose. The study findings showed that all application categories include many of the observed game elements but in different ratios; some game elements are more prominent than the other ones in some applications. We also observed that game elements operate (work) in interaction and they reflect the gamification as a whole consisting of many components.

Keywords: Gamification, Game elements, Game mechanics.

\footnotetext{
${ }^{1}$ Bu çalışma, "Oyunlaştırmada Oyun Elamanlarının Kullanımı: Adidas Micoach, Khan Academy, Superbetter ve Swarm Uygulamalarının Örnek Olay Yönetimi İle İncelenmesine Yönelik Keşifsel Bir Çalışma” ismi ile 2016 yılında A. Ü. S.B.E.'ye yüksek lisans tezi olarak sunulmuştur.
} 


\section{Giriş}

Oyun kavramı insanlık tarihi ile ilişkilendirilen bir kavram olmasına rağmen, oyunlar üzerine akademik çalışmalar geç başlamış; video oyunların ortaya çıkmasıyla yaygınlaşmıştır. Ancak video oyunlarının teknoloji yoğun yapısı, bu konuda yapılan çalışmaların da bu bağlamda ele alınmasını gerektirmiştir. Yapılan çalışmalarda genellikle oyunların teknik boyutuna ve oyuncuların eğlence temelli deneyimleri üzerine odaklanılmıştır (Ryan ve diğerleri, 2006). Pazarlama ya da iş dünyasında oyunlardan yararlanılması ise son yıllarda eğitim çalışmalarıyla kendini göstermiştir. Özellikle dijital teknolojilerin gelişmesi, internetin geniş kesimlere ulaşmasıyla beraber, oyuncu sayısı artmıștır. Bunun sonuncuda oyunlar, bireylerin boş zamanlarını değerlendirmede önemli bir uğraşı haline gelmiștir. Bireylerin, boș zamanlarını oyunlar aracılığıyla değerlendirmeleri ve günlük hayatlarının bir parçası olarak ele almaları, onların bir oyuncu kimliğine kavuşmalarını da kolaylaştırmıştır (Gosling ve Crawford, 2011, 150). Oyuncu kitlelerin artması, giderek artan sayıda oyuncu gibi düşünen ve birçok faaliyetten oyun-benzer deneyimler bekleyen, günlük aktivitelerini oyun-benzer bir șekilde yaşamak isteyen bir tüketici kitlesini ortaya çıkarmıștır (Herger, 2014). Bu eğilimin bir sonucu olarak oyunlaştırma uygulamaları 2010 yılından sonra eğitimin yanı sıra pazarlama ve diğer iş alanlarında da kullanılmaya başlanmıştır.

Oyunların eğlence dışında kullanımı eskiye dayanmaktadır. Ciddi oyunlar da denilen bu uygulamaların ilk örnekleri askeri eğitim amacıyla tasarlanmıştır. Modern anlamda ilk ciddi oyun, 1812 'de Prusya'da savaş taktiklerini öğretmek için geliştirilmiştir. İleriki y1llarda bugün de popüler olan Monopoly'nın atası sayılabilecek ve kapitalist ekonomik sistemi öğretmeye yönelik The Landlord's Game, İngiltere'de ortaya çıkmıştır (Adams ve Dormans, 2012, 272). $\mathrm{Bu}$ girişimlerin ardından özellikle eğitim ve askeri alanda simülasyonlardan yararlanılmış, video oyunlarından gelişmesiyle video oyun tabanlı eğitimler gerçekleştirilmiştir. 2000'li yıllara gelindiğinde ise iş dünyasında eğitim dışında oyunların kullanımı artmıştır. Oyuncu tüketicilerin artması kuruluşların ilgisini çekmiş ve marka iletişiminin bir parçası olarak reklam-oyunlar (advergames) ortaya çıkmıştır.

Sinemada olduğu gibi uzun yıllar oyunlara da marka ve ürün yerleștirilme şeklinde reklam stratejileri uygulanmıştır. Diğer yandan ürün yerleştirmeden farklı olarak reklam-oyunlar bir markanın etrafında gelişen bir senaryoya sahip reklam amaçlı geliştirilen oyunlardır. Bunlar özellikle belirli bir ürün, marka, hizmet ya da fikir için tasarlanmaktadır (Adams ve Dormans, 2012, 275; Terlutter ve Capella, 2013). Ancak reklam-oyunlar da ciddi oyunlar gibidir: Oyuncular oyuna başladıktan sonra bașka bir dünyaya dalmakta ve oyuncu kimliklerine bürünmektedir. Oyundan çıktıktan sonra ise gerçek kimliklerine kavuşmaktadır. Reklam-oyunlarda marka ile etkileşelim sadece oyun esnasında gerçekleşmektedir. Oyun bittikten sonra bu etkileşim ancak başka iletişim araçları ile sürmektedir.

Ciddi oyunlar üzerinden yapılan çalışmalar sonucunda, iş dünyasında oyunlar aracılığıyla davranıs rollerinin benimsenmesi, davranıșların öğrenilmesi, çalıșma hayatına oyunların dahil edilmesiyle motivasyon ve iş çabasının artırılması üzerine eğilmiştir. Bu bağlamda 2010'dan sonra Huizinga'nın (2006) "sihirli çember" (Her oyunun kendisine ait bir sanal dünyası vardır. Bir oyuncu oyuna başladıktan sonra başka bir dünyaya dalar ve gerçek dünyadaki kimliğini unutur.) olarak adlandırdığı, oyun alanın dışında da oyuncu kimliğin devam etmesini ve bireylerin oyundışı alanlarda da keyifli bir deneyim yaşamasına odaklanıldı. Bireyler, oyun-dışı alanlarda hem bir oyuncu hem de bir satış temsilcisi, operatör, müşteri temsilcisi, tüketici ya da asker olabilmektedir. $\mathrm{Bu}$ anlamda ciddi oyunların her uygulama için geliştirilmesi, oyun elemanlarının her tür sisteme entegre edilmesi; bu sistemleri eğlenceli ve katılımı yüksek bir uygulamaya dönüştürmüştür. Bu eğilim bugün için "oyunlaştırma" olarak bilinmektedir (Santhanam ve Liu, 2015, 5).

Oyunlaştırma kavramının yeni olması, bu konuda yapılan çalışmaların oyunlaştırmanın kavramsal yönünün açıklanmasına ve bir çerçevesinin belirlenmesine yoğunlaşmasına neden olmuştur (Deterding ve diğerleri, 2011; Huotari ve Hamari, 2012; Werbach, 2014; Herger, 2014; 
Kapp, 2014; Zichermann ve Cunningham, 2011). Litertürde sıklıkla Deterding ve diğerlerinin (2011) ortaya koyduğu tanım kullanılmaktadır. Buna göre oyunlaştırma: "oyun elemanlarının oyun dışı bağlamlarda kullanılmasıdır”. Diğer tanımlara baktı̆̆ımızda da oyun elemanlarının oyunlaştırmanın temel bileşenlerinden olduğunu görmekteyiz.

Oyun elemanları, oyun dışı alanlarda sıklıkla kullanılmasına rağmen oyun elemanlarının varlığı, birbirleri ile ilişkisi ve kullanıcılar üzerinde etkisi konusunda oyun literatüründe çok az çalışma bulunmaktadır. Hem tam oyunlar hem de oyunlaştırma için oyun elemanlarının ne olduğu ve birbirleri ilişkisi bazı modelleme çalışmalarında yer almaktadır. Araştırmalarda ise genellikle bu modellerden yola çıkarak yeni model önerilerinin sunulduğu (Werbach ve Hunter, 2012; Bunchball, 2012) ya da oyun elemanlarının kısmen araştırıldığı gözlenmektedir (Hamari, 2015; Suh ve diğerleri, 2015; McDaniel ve diğerleri, 2012; Sever ve diğerleri, 2015). Bu çabaların da işaret ettiği üzere, bir uygulamada oyun elemanlarının varlığının tespit edilmesi ve oyunla ilişkisinin ortaya koyulması, oyunlaştırma kavramının anlaşılması açısından önemlidir. $\mathrm{Bu}$ doğrultuda bu çalışma, örnek oyunlaştırma uygulamaları üzerinden oyun elemanlarının oyunlaştırma alanında kullanımına odaklanmıştır.

$\mathrm{Bu}$ çalışmada literatürde sıklıkla dile getirilen dört örnek oyunlaştırma uygulaması araştırmacı tarafindan kullanılmış ve oyun elemanları açısından incelenmiştir. Diğer yandan uygulamaların forumlarında içerik analizi yönetimi ile oyun elemanları ile ilgili kullanıcıların yorumları ele alınmıştır. Öncelikle hangi oyun elemanlarının kullanıldığı tespit edilmiş ve bunların uygulamaların oyun yapısına etkisi, oyun elemanlarının birbiriyle ilişkisi ve tüketici etkileşimi açıklanmıştır. Çalışmanın sonunda kullanılan oyun elemanları uygulamalara göre bir liste halinde verilmiş ve araştırmacının gözlemlemeleri ile kullanıcıların yorumları paylaşılmıştır.

\section{Oyunlaștırma Kavramı}

1900’lü yıllardan itibaren oyunlar aracılığıyla davranış rollerinin benimsenmesi ve iş alanına oyunların dahil edilmesiyle motivasyon ve iş çabasının artırılmasına dönük çabalar artmıştır. Ciddi oyunların her uygulama için geliştirilmesi, oyun elemanlarının her tür sisteme entegre edilmesi; bu sistemleri eğlenceli ve katılımı yüksek bir uygulamaya dönüştürmüştür (Santhanam ve Liu, 2015, 5). Uzun yıllar video oyunlar, simülasyon ya da entegre oyun uygulamaları ile oyunların oyun dışı alanlarda kullanılmasına yönelik çabalar, bugünlerde daha fazla oyunlaştırma uygulamalarında kendini göstermektedir.

Oyunlaştırma (gamification) kavramının en temel ve yalın açıklaması, bir şeyin oyunlaştırılmasıdır (gamify). Türkçe literatürde yeni olduğu kadar İngilizce'de de oyunlaştırma kavramının geçmişi eski değildir. Bu konuda ilk referanslar multiplayer çevrimiçi oyunlar üzerine araştırma yapan Essex Üniversitesi'nden Richard Bartle'e dayandırılmaktadır. Bartle, 1980'de "oyun olmayan bir şeyin oyunlaştırılması" olgusu için "gamifying” kavramını kullanmıştır. Gamification kavramı ise 2002 yılında İngiliz oyun geliştiricisi Nick Pelling tarafından elektronik araçlar için oyun-benzer (game-like) arayüzler oluşturmakla ilgili kullanılmış fakat o dönem için fazla ses getirmemiştir (Marczewski, 2013; Werbach ve Hunter, 2012, 25). Oyunlaştırma kavramının yaygınlaşması ise 2010 yılından itibaren iş dünyasında sıkça kullanılmasından sonra gerçekleşmiştir.

Oyun alanında oyunlaştırma teriminin kullanımı iki temel görüşe dayanmaktadır. İlk olarak video oyunların günlük aktivitelere adapte edilmesi, ubiquity (Aynı anda birçok yerde mevcut olma.) ve kurumsallaştırılmasıdır (Helgason ve Schell'den aktaran Deterding ve diğerleri, 2011). İkinci görüş ise en önemli amacı eğlence olan video oyunlarının -ki kullanıcılar, oyun sürecine yoğun bir katılım gösterir- motivasyon faktörlerinin oyun-dışı ürün ve servislere adapte edilmesi ve bu sayede eğlenceli ve katılımı yüksek uygulamalar oluşturmaktır (Zichermann ve Cunningham, 2011, XI-XII; Flatla ve diğerleri, 2011)

Oyunlaştırmayla ilgili çalışmaların yeni olması ve bu konuda yapılan akademik araştırmaların farklı disiplinlerden gelen bilim insanları tarafından ele alınması oyunlaştırmaya 
dair tanımların da çeşitliliğini doğurmuştur. Literatürde sıkça karşımıza çıkan tanım: Deterding ve diğerleri (2011) geliştirdiği kısaca "oyun elemanlarının oyun dışı bağlamlarda kullanılmasıdır."

Kapp (2012) ise eğitim yönlü bir yaklaşımla oyunlaştırmayı oyun mekaniklerinin kullanılmasıyla eğitim ve öğrenmenin daha eğlenceli hale getirilmesi olarak ifade etmektedir. Kapp (2012) daha ayrıntılı bir tanımda ise oyunlaştırmayı: "Oyun mekanikleri, estetikleri ve oyun düşünmenin (game thinking) insanların katılımının sağlanmasında, harekete geçmeye motive edilmesinde, problem çözmeye ve öğrenmenin desteklenmesinde kullanılması" şeklinde ifade etmektedir. Oyun elemanlarının kullanılmasıyla öğrenmenin oyuna benzetilmesi veya eğlenceli hale getirilmesiyle öğrenmenin desteklenmesi ve katılımın artırılması amaçlanmaktadır.

Oyunlaştırmayı pazarlama yönünden ele alan Zichermann ve Cunningham (2011, XII) ise oyunlaştırmayı: "Hedef kitlenin katılımının sağlanması ve problem çözme süreçlerinde oyun düşünme (game thinking) ve mekaniklerinin kullanılması" olarak tanımlanmaktadırlar. Oyunlaştırılan tasarımlar, belirlenen hedeflere ulaşmada yardımcı olmakta, belirli problemlerin çözümüne katkı sunmakta ve görevlerin tamamlanmasını kolaylaştırmaktadır (Huotari ve Hamari, 2012; Zichermann ve Cunningham, 2011).

Yukarıdaki tanımlardan da anlaşılacağı üzere oyunlaştırmanın en önemli unsuru oyun yapısının temel özelliği olan oyun elemanlarıdır. Oyun elemanları bir anlamda tam oyun veya oyun-dışı alanda bir uygulamanın oyunlarla ilişkisini belirleyen temel özelliklerdir. Bir uygulamanın oyun olarak belirtilmesi için gerekli göstergelerdir. Bu nedenle her oyun elemanı kullanan uygulama oyun değildir, ancak her oyun mutlaka oyun elemanlarına sahip olmalıdır.

\section{Oyun Elemanları}

Oyunlar entegre bir deneyim biçiminde kendini sunar ancak oyunun kendisi birçok parçadan medyana gelmektedir. Bu parçalar, oyun literatüründe oyun elemanları olarak adlandırılmaktadır. Deterding ve diğerleri (2011) oyun elemanlarını oyunların genelinde bulunan ve oyunların temel özelliklerini yansıtan parçalar olarak ifade etmektedir. Bu özellikler oyuncuların oyun içerisinde oynama deneyimi yaşamasıyla da ilişkilidir. Oyunlaştırma açısından ise oyun elemanları oyuna benzeyen bir uygulamanın tasarlanmasında farklı yollar sunan bir alet çantası gibidir (Werbach ve Hunter, 2012). Çantanın içinde yer alan her bir "alet" bir uygulamanın oyuna benzetilmesi veya oyun gibi algılanmasına yardımcı olacak çözümler sunmaktadır. Örneğin, bir uygulamaya lider tahtası eklenerek katılımcılar arasında rekabet yaratılabilir ya da uygulama içinde seviyeler oluşturarak, katılımcılarda seviye geçme sonucunda bir başarma duygusu yaşatılabilir.

Ciddi oyunlar, oyun tabanlı eğitim, reklam-oyunlar, eğlenceli-eğitim (edutaiment) vb. oyun dışı alanlar için geliştirilen birçok uygulamanın amacı, oyunlaştırmanın da en önemli amaçlarından olan oyun tasarım fikrini oyun dışı alanlara aktarmaktır. Bu sayede oyun elemanları ve yapısının entegre edildiği uygulama ve programlar aracılığıyla katılım ve keyifli deneyim hissinin oyun-dışı alanlarda da yaşanması arzulanmaktadır.

Özellikle pazarlama dünyasında eskiden beri puan ya da seviye gibi oyun mekanikleri müşteri sadakat programlarında (örneğin, mağaza kartlarıyla toplanan puanlar) kullanılmaktadır. Ancak oyunlaştırmanın başarısı tüketicilerden elde ettiği verileri gerçek zamanlı işleyerek ve bunları nişan, puan, lider tablosu gibi oyun mekanikleriyle yeniden gerçek zamanlı geri dönüşleri yapmasidır (Zichermann ve Linder, 2010).

Oyun-benzer bir uygulamanın yaratılmasında yararlanılabilecek birçok oyun elemanı bulunmaktadır. Ancak oyunlaştırmada amaç tam bir oyun yaratmak olmadığı için hepsinin kullanılması beklenmemektedir (Werbach ve Hunter, 2012) . Oyunlaştırmada çok fazla oyun elemanı kullanılmasından ziyade, iş hedefleri ve kullanıcılardan beklenen davranış değişikliğine göre oyun elemanları seçilmektedir.

Oyun elemanları, oyunların yapısal ve tasarım yönlerinin ele alınmasında kullanılan bir yaklaşımdır. Örneğin bir satranç oyunun parçaları şunlar olabilir: Diğer parçaların alınması için kareler arasında atlamak, parçaların en son sıraya (Şah) ulaşması için hareket ettirilmesi. 
$\mathrm{Bu}$ sistemde bazıları sadece birer nesne (parçalar) iken, bazıları ise ilişkiyi (atlamak, hareket ettirmek) gösterir. Ayrıca bu sisteme eklenen kurallar (tek kare atlamak) ve amaçlar (şahın ele geçirilmesi) vardır. Bu açıdan oyun bütüncül bir sistem olarak görülmesine rağmen, sistemin dayandığı birçok parça bulunmaktadır.

Oyun elemanlarının tespit edilmesi, onların sistem içindeki rollerinin de ortaya çıkarılmasını ve dolayısıyla kullanıcı ile etkileşimi sonucunda ortaya çıkan kullanıcı deneyiminin de anlaşılmasına yardımcı olacaktır. Bu bağlamda bir oyunlaştırma uygulamasında kullanılan oyun elemanları bir bütün olarak ele alındığında kullanıcılar arasında nasıl bir deneyim yaşattığ1 ve duygusal etkilerinin ne olabileceği öngörülebilir. Oyuncuların oyunlarla etkileşimi ve yaşadıkları deneyimlere odaklanan çalışmalar 2000'li yıllardan sonra artmış ve bu konuda birçok model geliştirilmiştir. Bugün oyun literatürde karşımıza en sık çıkan modellerden biri ise MDA (Mechanics, Dynamics, Aesthetics) modelidir.

\subsection{MDA Modeli}

Oyunların bir sistem olarak kabul edilmesi literatürde yaygın bir anlayıştır. Literatürde Hunicke ved diğerleri (2004) geliştirdikleri ve kısaca MDA olarak adlandırılan sınıflandırmanın yaygın olduğu görülmektedir (Deterding ve diğerleri, 2011; Zichermann ve Cunningham, 2011). Oyunlaştırmada da oyun elemanlarının açıklanmasında genellikle MDA modelinin temel alındığı görülmektedir (Werbach ve Hunter, 2012; Suh ve diğerleri, 2015; Santhanam ve Liu, 2015; Blohm ve Leimeister, 2013). Bu modele göre oyun süreci; oyun mekanikleri, dinamikleri ve estetikleri şeklinde birbirini etkileyen bir süreç biçiminde ilerlemektedir.

MDA modeli, oyun mekaniklerinin etkilerini göstermeye yönelik çok oyunculu oyunlar üzerinden geliştirilmiştir. Oyun sürecini sistem temelinde ele alan model, oyunu belli kuralları olan bir uygulama ve bu kurallara göre işleyen bir süreç olarak göstermektedir. MDA modeline göre; oyuncu-oyun etkileşiminde oyun elemanlarının temelini teşkil ettiği ve sonucunda keyif alınan bir süreç gerçekleştir. Keyifli deneyimler ise oyun elemanlarının birbiri ile ilişkisi sonucunda ortaya çıkmaktadır. Örneğin, lider tahtasının oyunda olması, rekabete neden olmakta ve lider sıralamasında üst sıralara çıkılması sonucunda başarma duygusu yaşanmaktadır. Sürecin yaratılmasında tasarım aşamasında kuralları mekanikler belirmektedir. Sistem, dinamikler olarak ifade edilirken, son aşamada oyuncuların süreçten aldıkları keyif deneyimi ise estetikler ile açıklanmaktadır. Buna göre oyunlar, bu üç bileşenin toplamından oluşmaktadır.

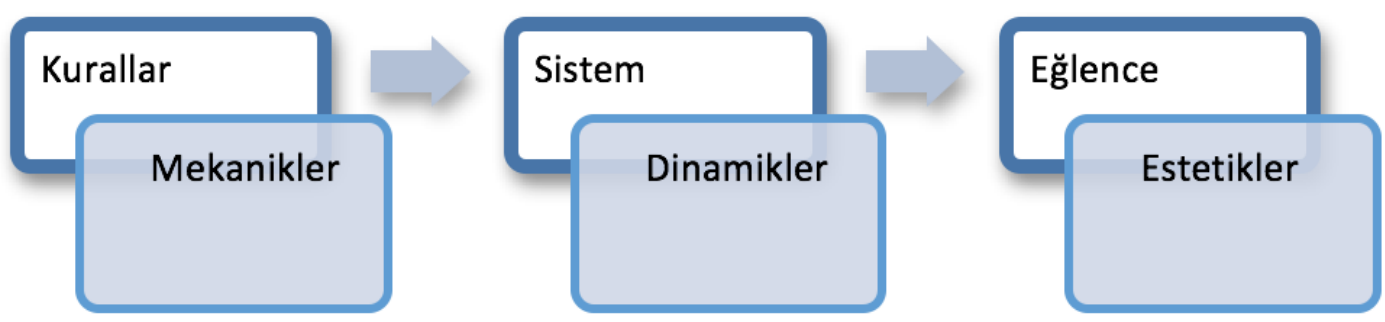

Şekil 1. MDA Modeli

Kaynak: Hunicke, LeBlanc ve Zubek, 2004

MDA yaklaşımına göre, oyun mekanikleri (puanlar, seviyeler, rozetler vs. ) oyun dinamiklerini ortaya çıkarır. Oyun dinamikleri ise oyun estetikleri ile sonuçlanır. Bir oyun üzerinden örnek vermek gerekirse; satranç oyununda mekanikler; oyun alanındaki her bir kareyi; bu kareler üzerinde dizilen taşları; bu taşların nasıl hareket edeceğini belirler. Piyonlar ilk çıkışta iki kare ilerleyebilir; diğer piyonları çapraz yer vb. tüm bu kurallar, oyunun temel düzenini ifade eder. Oyun dinamikleri, tüm bu hareketlerin, davranışların bir yansımasıdır. Mekanikler determinist biçimde dinamikleri ortaya çıkarır.

MDA modelinden yararlanarak, oyunlaştırmada da benzer modeller geliştirilmiştir (Werbach ve Hunter, 2012; Deterding ve diğerleri, 2011; Merino de Paz, Blanca, 2013; Robinson 
ve Bellotti, 2013). Ancak çok az çalışmada oyun elamanları bir oyunlaştırma uygulamasında incelenmiş ve bilimsel bir yöntem ile araştırılmıştır. Yapılan çalışmalar genellikle sektörel bir çabanın ürünüdür. Bunun yanı sıra yapılan az sayıda çalışma, oyun elemanlarının varlığ ve birebirleri ile ilişkisini genel olarak bir veya birkaç oyun mekaniği üzerinden incelemiştir (Hamari ve Koivisto, 2015; McDaniel ve diğerleri, 2012; Liu ve diğerleri, 2011).

Bazı mekanik, dinamik ve estetikler şunlardır:

- Mekanikler: puanlar, lider tablosu, ilerleme barı, seviyeler, rozetler ve avatarlar.

- Dinamikler: geri-bildirim, başarma, rekabet, işbirliği, statü ve kendini ifade etme.

- Estetikler: kısıtlamalar, duygular, anlatı, ilerleme, ilişkiler, duyular, fantezi, arkadaşlık ve keșif.

Mekanikler çok açıktır ve tahmin edilebilir unsurlardır. Ancak dinamikler için aynı şeyler söylenemez. Dinamikler, mekaniklere bağlı olduğu için nasıl ortaya çıkacağı veya ne tür dinamiklerin oluşacağını kestirmek güçtür. Oyuncunun bildiği ve zamanla öğrendiği şey ise mekanikler aracılığıyla dinamikleri yaratmaktır. Örneğin, her oyuncu belirli bir oyunda başarmak için seviyelerin geçilmesi gerektiğini bilmektedir.

Oyun mekanikleri, bir oyunun kuralları, süreçleri ve oyunun temel göstergesi olan verilerdir. Oyunun nasıl ilerleyeceğini, ne yapılacağını ve eğer kaybetme/kazanma var ise bunun koşullarını belirlemektedir (Adams ve Dormans, 2012, 1). Başka deyişle mekanikler, oyunların kural ve prosedürleridir. Bu bağlamda mekanikler, oyunun amaçlarını, oyuncunun başarıya nasıl ulaşacağını ya da ulaşamayacağını ve bunları yaparken hangi sonuçların ortaya çıkacağını belirlemektedir (Schell, 2014, 52). Mekanikler, oyun içeriğiyle birlikte oyuncuya çeşitli eylemler, davranışlar ve kontrol mekanizması imkanı sunmaktadır. Oyun içeriğiyle birlikte oyun dinamiklerini tetikleyen oyun mekanikleri bir ya da daha fazla dinamiğe ulaşma yolunu belirleyen araçlardır (Hunicke ve diğerleri, 2004). Örneğin statü dinamiğine (deneyim) ulaşmak için kullanıcının lider tahtasında yükselmesi ya da belirli bir seviyeyi geçmesi gerekir.

\section{Araştırma Sorusu}

Oyunlaştırma, hedef kitlenin katılımın sağlanması ve problem çözme süreçlerinde oyun düşünme (game thinking) ve mekaniklerinin kullanılmasıdır (Zichermann ve Cunningham, 2011, xi1). Oyun mekanikleri ise bir sistem olarak oyunun yapısını ve temel kurallarını belirleyen ve bir oyunda kullanıcıların yaşadığı oyun deneyimlerin temelini oluşturan yapıyı ifade etmektedir (Hunicke ve diğerleri, 2004). Bu bağlamda bu çalışmada oyunlaştırma sürecinde üç oyun elemanı (mekanik, dinamik, estetik) yerine sadece oyun mekanikleri gözlenmiştir. Dinamiklerin varlı̆̆ 1 ise oyuncularla birlikte çalışılması gereken başka bir araştırma desenini gerekmektedir. $\mathrm{Bu}$ çalışmanın odak noktası oyunlaştırma uygulamaları içinde hangi oyun elemanlarının kullanıldığg üzerine olmuştur.

$\mathrm{Bu}$ çerçevede bu çalışmanın temel problemi, oyunlaştırmada oyun elemanlarının varlı̆̆ 1 ve birbirleri ile nasıl bir etkileşim içinde olduğudur. Araştırma soruları ise şunlardır;

1. Oyun mekanikleri oyunlaştırma uygulamalarında kullanılmakta mıdır? Nasıl kullanılmaktadır?

2. Oyun elemanları arasında etkileşim ve uygulamalarda ortak özellikler bulunmakta mıdır?

\section{Sinırlılıklar}

Bu çalışma oyun elemanlarına odaklanmasına rağmen, oyun elemanlarından sadece oyun mekanikleri ele alınmıştır. Araştırmaya konu örnek olayların kullanıcılarına gerçek hayatta ulaşma imkanının kısıtlı olması ve internet üzerinden cevapların alınmasında güçlüklerin olduğu öngörülerek, oyun dinamik ve estetikleri araştırmaya dahil edilmemiştir. 
Çalışmada sadece Adidas miCoach, Khan Academy, SuperBetter ve Swarm uygulamaları seçilmiştir. Çalışmanın süresi ve verilerin elde edilmesinde gerekli zaman ile araştırmacının elindeki kaynaklar göz önünde bulundurularak dört örnek olayın ele alınmasına karar verilmiştir.

\section{Yöntem}

Bu çalışmada nitel araştırma yöntemlerinden biri olan örnek olay araştırma modeli tercih edilmiştir. Örnek olay çalışması; bir olay (tek olay çalışması) ya da az sayıda olayın (karşılaştırmalı örnek olay çalışması) geçtiği gerçek yaşam bağlamında seçilmesi ve bu olaylardan elde edilen verilerin nitel bir yaklaşımla analiz edilmesidir (Dul ve Hak, 2008, 8).

Örnek olay çalışmaları, güncel bir olguyu kendi gerçek yaşam çerçevesi içinde çalışan, olgu ve içinde bulunduğu içerik arasındaki sınırların kesin hatlarıyla belirgin olmadığı ve birden fazla kanıt veya veri kaynağının mevcut olduğu durumlarda kullanılan, görgül bir araştırma yöntemidir (Şimşek ve Yıldırım, 2013, 277). Ancak burada sınırları tam olarak bilinmemesi, bu konuda yeterli kuramsal açıklamaların olmamasıyla ilgilidir; yoksa araştırmanın sınırsız bir alanda yapılması anlamına gelmemektedir.

Dul ve Hak'a (2008: 21) göre; örnek olay çalışması, pazarlama, işletme ve strateji gibi birçok alanda yararlanılan geçerli bir araştırma stratejisidir ve özellikle çalışılmak istenen konu şu özelliklere sahip olduğunda bir araştırma yöntemi olarak yararlı olacağı vurgulanmaktadır;

- Konu, geniş ve son derece karmaş1k olduğu taktirde,

- Konu hakkında çok fazla teori olmadığında,

- Konu bağlamının çok önemli olması durumunda.

Oyunlaştırmanın yukarıdaki özelliklerin birçoğunu karşıladığı düşünülmektedir. Oyunlaştırma, yeni bir kavram olmasının yanı sıra bu alanda görgül araştırmaların az ve oyunlaştırmayı açıklamaya yönelik kuramsal açıklamaların başlangıç aşamasında olduğu yapılan literatür çalışmasından anlaşılmaktadır. Bunun yanı sıra bu çalışmanın temel problemini teşkil eden oyun elemanları ile ilgili de benzer şekilde kuramsal bir açıklamanın olmadığı, daha çok modelleme çabalarının olduğu görülmektedir.

Oyun elemanları, oyunlaştırma tanımlarında sıklıkla söz edilen ve bir uygulamanın oyunbenzer bir niteliğe sahip olduğunun göstergesidir (Deterding ve diğerleri, 2011). Bu anlamda oyunlaştırmada hangi oyun elemanlarının kullanıldığ ve oyun olmayan bir içeriğin oyun-benzer kı1ınmasında oyun elemanlarından nasıl yararlanıldığının açıklanması, oyunlaştırma konusunun anlaşılması için de önemlidir. Bu nedenle hem genel anlamda oyunlaştırma hem de oyun elemanlarının incelenmesinde örnek olay incelemesinin araştırma amaçlarına ulaşmada yararlı olacağı öngörülmektedir.

\section{1. Örnek Olayın Seçimi}

Örnek olayın seçimi araştırma amaçlarına ulaşılmasında kritik bir etkiye sahiptir. Bu aşamada çalışmanın soruları göz önünde bulundurularak, örnek olaylar ve birimler seçilmiştir

Genel olarak dört temel örnek olay deseninden söz edilebilir.

Tablo 1. Örnek Olay Desenleri

\begin{tabular}{|l|l|l|}
\hline & Tek durum desenleri & Çoklu durum desenleri \\
\hline Bütüncül (tek bir analiz birimi) & Tek bir örnek olay & Birçok örnek olay \\
\hline İç içe geçmiş (çoklu analiz birimi) & $\begin{array}{l}\text { Tek bir örnek olay ancak birkaç } \\
\text { analiz birimi }\end{array}$ & $\begin{array}{l}\text { Birçok örnek olay ve analiz } \\
\text { birimi }\end{array}$ \\
\hline
\end{tabular}

Kaynak: (Yin, 2003, 40)

$\mathrm{Bu}$ araştırma, oyunlaştırmada oyun elemanların varlı̆̆ ve kullanım biçimine yoğunlaşmaktadır. $\mathrm{Bu}$ nedenle tek bir örnek olaydan ziyade birkaç örnek olayın birlikte ve karşılaştırmalı bir şekilde ele alınmasının, oyun elemanların nasıl kullanıldığını anlamaya 
yardımcı olacağı düşünülmektedir. Önceki bölümlerde söz edildiği gibi, oyun elemanlarının işlevleri konusunda yeterli kuramsal açıklamalara oyun literatüründe rastlanmamaktadır. Oyun elemanlarının farklı örnek olaylar üzerinden analiz edilmesinin, ileride kuramsal bir çerçevenin oluşturulmasına hizmet edeceği düşünülmektedir. Ayrıca oyunlaştırma ile ilgili genel bir olgunun (oyun elemanları) tek bir örnek olayın üzerinden analiz edilmesinin eksik bilgiler sunacağı öngörülmektedir. Bu bilgiler ışığında bu çalışmada dört farklı oyunlaştırma uygulaması araştırma birimi olarak ele alınmıştır.

Seçilen uygulamalar ve özellikleri şunlardır:

- Adidas miCoach, Adidas'ın, teknoloji ve oyun unsurlarını bir arada sunan birçok ürünü miCoach adıyla birleştirdiği bir platformdur. Farklı alanlarda geliştirdiği ürünlerden alınan verileri Adidas miCoach sitesi üzerinden takip edilmektedir. Sitenin en önemli özelliği oyunlaştırılmış bir deneyim sunmasıdır. Site bu hizmeti ücretsiz olarak sunmaktadır. Yaygın olarak kullanılan bu ürünler aşağıdaki gibidir: Smart Run, Speed_Cell ve X-Cell, miCoach Smart Ball ve Adidas Train \& Run Mobil Uygulaması.

- Khan Academy, 2006 y1lında kurulan popüler bir ücretsiz online eğitim sitesidir. İlk zamanlar sadece uzaktan eğitim amaçlı videolar paylaşıyordu. Ancak daha sonra yenilikçi bir bakış açısıyla sitede oyun elemanlarını kullanan site, bu sayede kullanıcıların katılmalarını artırmıştır. Eğitim almanın yanı sıra rozetler ve puanlar toplamak isteyen katılımcılar, oyun oynarken aynı zamanda öğrenmektedir (Bruenner, 2011).

- SuperBetter sitesi, bireylerin ruhsal ve fiziksel zindeliğe ulaşmalarına yardımcı olmaya dönük, oyun alanında akademik ve sektörel çalışmalar yapan Jane Mcgonial tarafından geliştirildi. Site, aktif ve zinde bir yaşam sürmek isteyen insanlara bu amaçlarını gerçekleştirmede oyun-benzer bir deneyim sunarak motive etmektedir.

- 2009 y1lında kurulan Foursquare'in geliştirdiği bir mobil uygulama olan Swarm, Foursquare'ın mekanların bildirimi ve mekanlar hakkında yorum yapma özelliğini oyunlaştırma deneyimine dönüştürmüştür. Uygulama aynı zamanda bir sosyal ağ olarak da işlev görmektedir. Foursquare ile birçok benzerlik taşıyan Swarm, oyun mekaniklerini daha fazla geliştirerek, kullanıcılara daha fazla oyunlaştırılmış bir sosyal ağ deneyimi sunmaktadir .

Bu uygulamaların seçilme nedenleri ise, aşağıda verilmektedir:

Adidas miCoach

- Literatürde iyi bir oyunlaştırma uygulaması olarak vurgulanması (Knaus, 2015; Yamagiwa vd., 2015)

- Birçok oyunlaştırma uygulaması verilerinin bir platformda toplaması (iOS, android, playstation, miCioach giyilebilir spor aksesuarları).

- Kullanıcı sayısının çokluğu (Üç milyon).

- Yine başarılı bir oyunlaştırma uygulaması olarak örnek gösterilen ve bu alanda ilk çıkan oyunlaştırma uygulamalardan Nike+'a göre daha fazla aktivite seçeneği sunması.

Khan Academy

- Eğitim alanında örnek bir uygulama olarak gösterilmesi (Thompson, 2011)

- Yine iyi bir oyunlaştırma uygulaması olarak ele alınması (Deterding, 2012)

- Araştırma sürecinde ulaşabilir ve inceleme açısından kolay bir tasarıma sahip olması

\section{SuperBetter}

- Oyun ve oyunlaştırma alanında akademik ve sektörel olarak başarılı bulunan bir tasarımc1ya ait olması (McGonigal, 2010) 
- Oyunlaştırmanın yaygın kullanıldığı spor, pazarlama ve eğitim gibi farklı bir alana (psikolojik esenlik) yönelik olması

Swarm

- İlk yaygın oyunlaştırma uygulamalarından biri olarak ele alınan Foursquare'in bir devamı olmas1 (Evans ve McKee, 2010: 171)

- Başarılı bir oyunlaştırma uygulaması olarak ele alınması (Foxman, 2014)

- Pazarlama iletişimine yönelik sosyal medya içerikli yeni yöntemler sunması

- Yeni bir uygulama olmasına rağmen bireyler tarafindan benimsenmesi ve kullanıc1 sayısındaki artış (Smith, 2016)

- Diğer seçilen uygulamalara nazaran Türkiye'de de yüksek bir kullanıcı kitlesinin mevcut olması (Ferah, 2015)

\subsection{Veri Toplama Tekniği}

$\mathrm{Bu}$ çalışma iki veri toplama tekniği bir arada kullanılmıştır. Araştırmada veri toplama süreci aşağıda yer aldığı gibi gerçekleşmiştir.

- Bu çalışmanın yürütücüsü ilgili dört oyunlaştırma uygulamasını 2 aylık bir sürede kullanmıştır. Bu süre içinde oyun elemanlarının nasıl ve neden kullanıldığı üzerine notlar alınmıştır.

- Literatür araştırmasından yola çıkarak, oyun elemanlarından mekaniklerin bir listesi aşağıdaki gibi oluşturulmuş ve araştırma sürecinde gözlemlere dayalı olarak bu liste geliştirilmiştir. Liste içindeki her mekanik birer anahtar kelime olarak kodlanmış ve uygulamaların içerisindeki tartışma ortamlarında bu kelimelerin İngilizce karşılıkları aratılmıştır.

Tablo 2. Analiz edilen ve gözlemlenen oyun mekanikleri listesi

\begin{tabular}{|c|c|c|}
\hline Lider Tablosu (leaderboard) & Sanal Mallar (virtual goods) & Koleksiyonlar (collections) \\
\hline Puanlar (Points) & Rozetler (badges) & Mücadeleler (challanges) \\
\hline Seviyeler (levels) & Avatar (avatar) & Başarı Sembolleri (achievements) \\
\hline Kişileştirme (customization) & Profil (profile) & Yarışmalar (competition) \\
\hline Görevler (tasks, mission) & $\begin{array}{l}\text { Şans ve Beklenmedik Mekanikler } \\
\text { (chance) }\end{array}$ & İçerik Açıcı (content unlocking) \\
\hline Sosyal Grafikler & Gruplar (groups, teams) & Bildirimler (notification) \\
\hline $\begin{array}{l}\text { Gösterge Tablosu } \\
\text { (Dashboard) }\end{array}$ & $\begin{array}{l}\text { Sosyal Paylaşım Noktaları } \\
\text { (social networks) }\end{array}$ & Tartışma Ortamları (discusion) \\
\hline Hediyeleşme (gifting) & & \\
\hline
\end{tabular}

Her bir mekanik bir anahtar kelime olarak aratılmıştır. Örneğin lider tablosu için arama şu şekilde yapılmıştır: "leaderboard site:community-micoach.adidas.com/"

Benzer aramalar diğer örnek olaylar için de yapılmıştır. Sadece "Swarm" uygulamasının bir tartışma platformu olmadığından benzer bir işleve sahip Twitter hesabından yararlanılmıştır. Bunun yanı sıra blog sayfası da veri kaynağı olarak kullanılmıştır.

Bu aramalar 1 nisan 2016 ve 30 nisan 2016 arasında bir aylık bir zaman dilimi içinde yapılmıştır. Bir verinin tekrar ve birkaç kez alınmasını önlemek adına iki yola başvurulmuştur; birincisi bir anahtar kelime aranmaya başlandığında, arama sonuçlarının derlenmesi ve gerekli verilerin ele edilmesine kadar o anahtar kelime ile araştırmanın devam edilmesi ve sonunda o anahtar kelimenin bir daha aranmaması. İkincisi ise arama motorunun tıklanan adresleri işaretlemesinden yola çıkarak, bir adrese eğer tıklanmış ise bunlar analiz kapsamına tekrar alınmamıştır. 


\section{Bulgular}

Her dört uygulama için aşağıda puanlar özelinde örneği verildiği gibi bulgular elde edilmiştir. Tablo 3'de gösterilen tüm mekaniklerin ve aynı zamanda uygulamalar incelenirken karşılaşılan diğer mekanikler gözlenmiş ve bunların uygulama içinde nasıl çalıştığı, diğer mekanikler ile ilişkisi açıklanmıştır.

Çalışmanın uzunluğu nedeniyle aşağıda sadece puan mekanikleri ile ilgili bulgular örnek olarak verilmektedir. Son tabloda ise nicel olarak mekaniklerin varlı̆̆ 1 dört uygulama için gösterilmektedir.

\subsection{Puan Mekaniğinin Kullanımı}

\subsubsection{Adidas miCoach'da puanların kullanımı}

miCoach'da birçok ürün ve uygulamadan ele edilen veriler birer puana dönüşür ve kullanıcının profiline yansıtılır. Puanlar hangi aktivite yapılıyor ise, onunla ilgili olmaktadır. Örneğin koşuda bu puanlar, belirli bir mesafenin koşulması veya bir mücadelenin başarılmasından elde edilen verilere dayanmaktadır. Smart Ball ile yapılan futbol antrenmanlarında ise yapılan vuruşların hızı, mesafesi gibi verilere dayanmaktadır.

Sitede yer alan puanlar, üç biçimde kullanılmaktadır. Bunlar; deneyim, beceri ve itibar puan sistemleridir. Oyuncular, koşarken veya Smart Ball ile yaptıkları antrenmanlarda başarılarına göre belirli puanlar alır. Burada alınan puanlar onların başarı sembollerine ve eğer bir grup içinde yer alıyorsa lider tablosundaki konumlarına etki etmektedir.

Bunların yanı sıra her kullanıcının bir statü seviyesi bulunmaktadır. Statü seviyesi ise kullanıcıların yaptıkları antrenmanların dışında site içindeki birçok faaliyetten elde ettikleri puanlar ile ilgilidir. Bir sporcu antrenmanlar dışında aşağıdaki aktivitelerden elde ettiği puanlara göre statüsünde bir değişim olmaktadır:

- Tartışma bölümünde herhangi bir içerik üzerine yorum yapılması,

- Başka bir kullanıcıyı takip etmesi,

- Başka bir kullanıcının kendisini takip etmesi,

- Kendisinin yaptığı bir yorumu başka bir kullanıcının beğenmesi,

- Birisinin statüsünü beğenmesi,

- Bir tartışmaya cevap vermesi,

- Bir etkinlik grubu oluşturması,

- Bir tartışma ortamı yaratması,

- Sosyal bir grup oluşturmas1,

- miCoach uygulamalarından birini yüklemesi,

- Herhangi bir soruya doğru cevap vermesi.

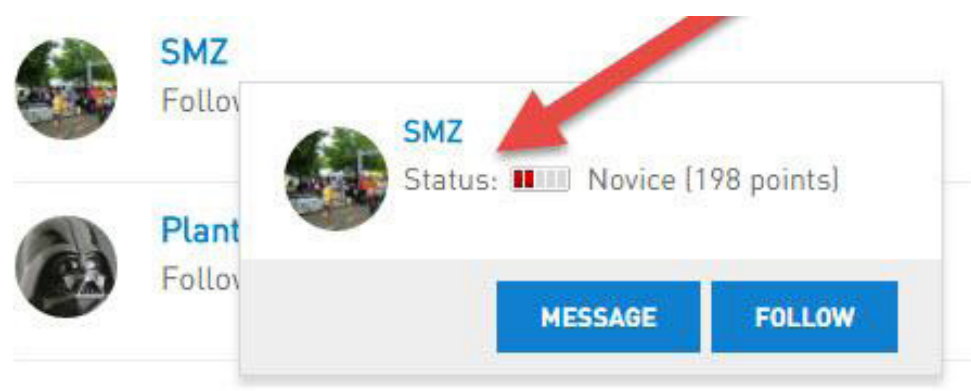

Șekil 2. miCoach Statü Puanları 


\subsubsection{Khan Academy'de puanların kullanımı}

Khan Academy'de de puanlama sistemi site içinde bulunan birçok oyun elemanı ile bağlantılı çalışmaktadır. Sitede kazanılan bu puanlara "Enerji" puanları adı verilmektedir ve pek çok mekanikle ilişkilidir.

Khan Academy, kullanıcıların bir ders vidosunu sonuna kadar izlemelerini ve ders alıştırmalarını da aynı şekilde tamamlamalarını istemektedir. Kullanıcıları buna teşvik etmek için onların ders videolarını izlerken geçirdikleri her bir süreyi puanlamakta ve buna göre ders bitiminde toplam bir puanla ödüllendirmektedir. Örneğin, bir ders videosu izlediğinde 100 enerji puanı kazanması beklenirken, vidoyu hızlı oynattığında ya da hiç izlemediğinde elde edeceği puanlar azalacaktır.

Enerji puanları büyük ölçüde dersler ile ilgili iken, başka görevler de yerine getirildiğinde aynı şekilde enerji puanları kazanılabilmektedir. Özetle site içerisinde aşağıdaki faaliyetlerinden enerji puanları kazanılmaktadır:

- Kullanıcılar, herhangi bir bilgisayar programı görevini tamamladıklarında 1500 - 2000 arası bir puanı elde ederler. Puanlar, görevlerin zorluğuna göre değişmektedir.

- Khan Academy, kullanıcıları daha fazla öğrenmeye teșvik etmek için kullanıcılara ilk kez bir video izlemeye başladığında 750 enerji puanı verir. Video tam olarak izlendiğinde ise 100 puan daha verilir.

- Aynı şekilde ikinci ve üçüncü defa video izlediklerinde de puanlar kazanılar.

- Kullanıcılar, yaptıkları alıştırmalarda ve uzmanlık görevlerinde doğru cevap verdiği her bir sorudan puan alırlar.

- Kullanıcılar, aynı zamanda önemli bir sınavı tamamladıklarında puan kazanılar.

- Bunların yanı sıra kullanıcılar, kazandıkları rozetler için de puanlar kazanılar.

- Kullanıcılar, tartışma bölümlerinde cevap verdiğinde puan kazandığı gibi; aynı zamanda cevapların doğru olmasına göre de daha fazla puan kazanmaktadır.

- Kullanıcılar, aynı zamanda tartışma bölümlerinde soru sorduklarında da puan kazanmaktadır.

TOTAL ENERGY POINTS EARNED

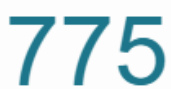

675 Points for questions

11 questions answered $82 \%$ correctly

100 Points for completion

Bonus points earned for completing this task

Şekil 3. Khan Academy Alıştırmalar Sonrası Kazanılan Puanlar

Kullanıcılar ne kadar enerji puanı kazandıklarını yukarıdaki faaliyetleri yerine getirdiklerinde, beliren "streak" bölümünden öğrenebilirler. Toplam puanları ise hem profil sayfalarında hem de sayfanın sağ üst köşesinde daima yer almaktadır.

\section{8,132 @ $400 \bigcirc 0 \bigcirc 1 \bullet 6 \bigcirc 26$}

Şekil 4. Khan Academy Puanlar

Elde edilen puanlar site içinde diğer mekanikler ile de ilişkili olarak, başka kazanımların da elde edilmesine yol açmaktadır. Belirli bir enerji puanına birçok rozet otomatik olarak 
kullanıcının profiline eklenir. Diğer yandan kullanıcılar, avatarlarını (Kişilerin profillerindeki kimlik yerine geçen görsele Avatar denilmektedir. Hint mitolojisinde farklı kimliklere bürünme olarak anlamına gelir) değiştirmek istediklerinde enerji puanlarını kullanabilirler. Ancak burada kullanılan enerji puanları bir satın almadan ziyade belirli bir puana ulaştıkları için avatarlarını değiştirmeye izin verilmesidir. Örneğin, "Amelia" avatarının ilk versiyonunu almak için kullanıcının 50 bin enerji puanına ulaşması gerekir.

\subsubsection{SuperBetter'da puanların kullanımı}

SuperBetter'da puanlama sistemi görevlerin tamamlanması ve seviyelerin aşılması gibi diğer mekaniklerle ile ilişkili olarak kazanılmaktadır. SuperBetter'a göre bireylerin esenliği dört temel faktöre bağlıdır. Bunlar; fiziksel, zihinsel, duygusal ve sosyaldir. Bu doğrultuda sitede puanlar bu yaklaşıma bağlı olarak verilmektedir. Son aşamada ise bu puanlar toplanarak kullanıcının esenlik puanı ortaya çıkmaktadır. Aşağıdaki grafikte görüleceği üzere bir kullanıcının dört farklı türde puanı bulunmaktadır. Puanlar doğrudan başarılan görevler ile ilgili olmaktadır. Kullanıcı hangi alanda daha fazla görev alıp, bunu başardıysa o alanda daha fazla puana sahip olmaktadır. Aşağıdaki örnekte, kullanıcının başardığı görevler daha çok zihinsel düzey ile ilgilidir. Aynı zamanda puanlar, var olan (current) puanlar ve ulaşılan en üst (peak) seviye olarak ikiye ayrılmaktadır. Ancak oyun sürecinde neden bu şekilde ayrıldığı ve hem var olan puanların hem de en üst düzey puanların neden hep aynı oranda yükseldiği anlaşılamamıştır.

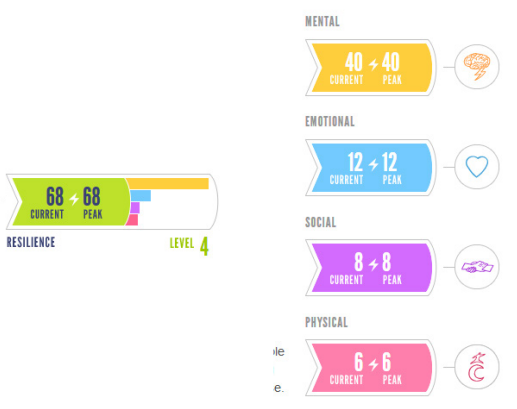

Şekil 5. SuperBetter Puanlama Sistemi

\subsubsection{Swarm'da puanların kullanımı}

Swarm'da puanlar, yerine "coins (jeton)" tanımı kullanılmaktadır ancak kullanım olarak puanlardan bir farkı bulunmamaktadır. Swarm'da puanlama sistemi kullanıcıların, ziyaret edilen mekanlardan yaptıkları Check-in'lere bağlı olarak çalışmaktadır. Ancak yine temelde Check-in olmasına rağmen, aşağıdaki aktivitelerden de puan kazanmaktadırlar:

- Kullanıcı arkadaşından önce bir mekana giriş yapıp, check-in yaptığında,

- Kullanıcı, aynı mekanda arkadaşı ile birlikte check-in yaptığında,

- Etiketler kullanılarak check-in yapıldığında bonus puanların kazanılması,

- Kullanıcı bir etkinliğe katıldığında bu etkinliği belirtilerek check-in yapması,

- İlk defa bir mekanda check-in yapılması,

- Lider tablosunda en üstte yer almak (Mayorship). 


\subsection{Oyun Elemanlarının Kullanımında Uygulamalar Arasında Benzerlikler ve Farklılıklar}

Tablo 3. Incelenen Örnek Olayların Karşılaştırılması

\begin{tabular}{|c|c|c|c|c|c|}
\hline \multicolumn{2}{|c|}{ Oyun Mekanikleri } & $\begin{array}{c}\text { Adidas } \\
\text { miCoach }\end{array}$ & Khan Academy & SuperBetter & Swarm \\
\hline \multicolumn{2}{|l|}{ Puanlar } & $\bullet$ & - & - & - \\
\hline \multicolumn{2}{|l|}{ Seviyeler } & $\cdot$ & $\cdot$ & - & \\
\hline \multicolumn{2}{|l|}{ İlerleme Barı } & - & - & & \\
\hline \multicolumn{2}{|c|}{ Sanal Mallar ve Alışveriş } & & 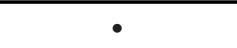 & & - \\
\hline \multicolumn{2}{|c|}{ Koleksiyonlar } & $\bullet$ & $\bullet$ & $\bullet$ & $\bullet$ \\
\hline \multicolumn{2}{|c|}{ Lider Tablosu } & $\bullet$ & & & $\bullet$ \\
\hline \multicolumn{2}{|l|}{ Mücadeleler } & $\cdot$ & - & - & \\
\hline \multicolumn{2}{|c|}{$\begin{array}{l}\text { Rozetler ve Başarı Sembol- } \\
\text { leri }\end{array}$} & $\bullet$ & $\bullet$ & $\bullet$ & $\bullet$ \\
\hline \multirow{2}{*}{ Kişileştirme } & Profiller & 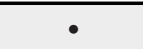 & $\cdot$ & & - \\
\hline & Avatarlar & & $\bullet$ & & \\
\hline \multicolumn{6}{|c|}{ Hediyeleşmek } \\
\hline \multicolumn{2}{|l|}{ Görevler } & - & - & $\bullet$ & \\
\hline \multicolumn{6}{|l|}{ Yarışmalar } \\
\hline \multicolumn{2}{|c|}{$\begin{array}{l}\text { Şans ve Beklenmedik } \\
\text { Elemanlar }\end{array}$} & & & & $\bullet$ \\
\hline \multicolumn{2}{|l|}{ İçerik Açıcı } & & $\bullet$ & $\bullet$ & - \\
\hline \multicolumn{2}{|c|}{ Sosyal paylaşım noktaları } & $\cdot$ & $\cdot$ & $\bullet$ & $\bullet$ \\
\hline \multicolumn{6}{|c|}{ Sosyal Grafikler } \\
\hline \multicolumn{2}{|l|}{ Gruplar } & 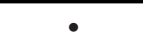 & & - & - \\
\hline \multicolumn{2}{|l|}{ Bildirimler } & - & - & - & - \\
\hline \multicolumn{2}{|c|}{ Gösterge Tablosu } & $\bullet$ & $\cdot$ & & \\
\hline \multicolumn{2}{|c|}{ Ayarlar } & - & 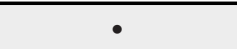 & & - \\
\hline \multicolumn{2}{|l|}{ Hedefler } & $\bullet$ & $\bullet$ & $\bullet$ & \\
\hline \multicolumn{2}{|c|}{ Tartışma Ortamları } & - & - & - & - \\
\hline
\end{tabular}

\subsubsection{Oyunlaştırma sürecinin temel göstergesi ve para değeri olarak puanlar}

Tablo 3'de da görüleceği üzere tüm oyunlaştırma uygulamalarında puanlar kullanılmaktadır. Puanlar, bir oyunlaştırmanın işleyiş sürecinin belirleyen temel unsurlardan birisidir. Oyunlaştırma literatüründe PLB (Point, Leaderboard, Badges) üçlemesi olarak geçen (Werbach ve Hunter, 2012: 86) sistem içinde üç mekanikten biri olan puanlar, oyunlaştırma siteminin temel yapısını teşkil etmektedir

Puanlar, bir oyunlaştırma uygulamasında oyuncuların ilerlemesini, bildirimlerin iletilmesini, kazanma durumunu, sonuçların aktartılmasını ve lider tablosu ya da rozetler gibi diğer pek çok mekaniğin işleyişini belirleyen bir unsurdur. Puanların bu işlevleri, video ya da geleneksel diğer oyunlarda da görülebilir ancak dijital oyunların yapısı puanların işlevini de farklılaștırmıș ve birer değiș-tokuș aracına da dönüștürmüștür. Bu açıdan puanlar, bir anlamda parasal bir değer de ifade etmektedir. Bu durum puanları; gerçek hayatta benzer bir ekonomik strateji ile yönetilmesi gereken bir varlığa da dönüştürmektedir.

Puanların bu şekilde kullanımı sanal para mekaniğini ve alışverişi de ortaya çıkartmaktadır. İncelenen dört örnek olay içinde sadece Swarm ve Khan Academy'de sanal paranın yer aldığ 1 görülmektedir. Khan Academy'de puanlar, bazı mekaniklerde ekstra yetkiye ya da özelliklere sahip olmayı sağlamasına rağmen kullanıcının puanları üzerinde tasarruf yetkisi olmadığından 
dolayı gerçek bir sanal alışverişten söz etmek güçtür. Swarm'da ise, puanların biriktirilmesi, harcanması ve daha fazla biriktirmeye yarayan bir sistem kurulmuştur. Swarm'da puanların bu şekilde kullanım nedenin kullanıcılar arasında daha fazla check-in yapmayı teşvik etmeye dönük olduğu öngörülmektedir. Daha fazla check-in yapılarak daha fazla puan kazanılabilmekte ve bunun sonucunda bir anlamda sanal bir servetin yaratılması mümkün olmaktadır.

Daha önce Foursquare'de kullanıcılar, puanları ile gerçek hayatta bazı kazanımlar elde etmekteydiler. Örneğin, bir mekanda en fazla check-in yapan kullanıcı o mekanda ücretsiz bazı ikramlar kazanabiliyordu. Swarm, sürekli geliştirilmesine ve şuan için 3.0 versiyonu kullanılmasına rağmen, puanların nasıl harcanacağı konusunun tam olarak çözülemediği, kullanıcıların tepkileri ve onlara verilen cevaplardan anlaşılmaktadır. Kullanıcıların birçoğu daha önce Foursquare'de olduğu gibi kazanılan puanların gerçek hayatta harcanabilecek bir değere dönüştürülmesini istemektedirler. Aşağıda bu yönde bazı kullanıcıların taleplerini içeren ifadeler yer almaktadır:

Tim O’Neil: "Neden jetonları gerçek değerlerde vermiyor ve bunları bir kahve ya da başka bir şey için harcamak için imkan yaratmıyorsunuz?"

Letty Mendoza: Jetonlarla ilgili herhangi bir geliştirme? Sadece etiketler için kullanmak istemiyorum"

Benzer talepler Khan Academy kullanıcılarından da gelmekte ve onlar da puanların sanal ve gerçek hayatta harcanabilecek değerlere dönüştürülmesini talep etmektedirler. "Tehya" adlı kullanıcı site yöneticilerden şöyle bir talepte bulunmaktadır:

"Enerji puanlarını okul eşyaları veya okulumuzdaki öğretmenlere hediye vermek gibi amaçlarla harcama imkanı sunacak mısınız?"

Diğer bir kullanıcı ise anonim bir isimle şunu talep etmektedir:

"Enerji puanlarını harcayacak bir sanal dükkan yapın"

$\mathrm{Bu}$ konun altında birçok kullanıcı bu talebi beğendiklerini ve iyi bir fikir olduğu belirtmektedirler.

\subsection{2. İlerleme ve Seviyeler}

Tablo 3'ün ortaya koyduğu diğer bir durum ise miCoach ve Khan Acedemy'de ilerleme barı yer alırken, diğerlerinde (SuperBetter, Swarm) rastlanmamaktadır. Bu özelliğin uygulamalar arasında farklılık arz etmesi; oyunlaştırmanın kullanıcıyı belirli bir başlangıç aşamasından başlatarak, yine belirli bir hedefe yöneltmek amacında olup olmadığı ile ilgilidir. Bu durum doğal olarak oyunlaştırma içinde hedefler mekaniğinin de kullanılmasını gerektirmektedir. Hedefler, ilerleme barı kullanan miCoach ve Khan Academy'nin her ikisinde de yer almaktadir. SuperBetter' da da hedefler yer almaktadır ancak buradaki mekanik genel oyunlaştırma sürecinin dışında olduğu için doğrudan bir ilerleme göstergesine ihtiyaç duymamaktadır. Hedefler, aynı zamanda buna ulaştıracak yolların da belirlenmesini gerektirmektedir. Bu nedenle ilerleme barı ve hedeflerin olduğu miCoach ve Khan Academy'de aynı zamanda hem görevler hem de seviye mekaniği yer almaktadır. Seviyeler, kullanıcıları, ilerleme adımları belli olan bir yol haritası içinde belirli aşmalardan geçirerek hedefe ulaştırır. Görevler ise bu aşamalarda kullanıcının üstesinden gelmesi gereken mücadele alanlarını göstermektedir.

Tablo 3'de görüleceği gibi; Swarm'da bu mekaniklerin hiçbirine rastlanmamaktadır. Swarm, bir sosyal medya uygulaması olduğundan dolayı kullanıcılara başlangıcı ve sonu olan bir süreç sunmamaktadır. Bu yüzden, puanların bir ekonomik araç olarak kullanılması ve biriktirilmesine önem verirken, seviye ya da görevler gibi sınırlı bir zaman dilimine işaret eden mekanikleri kullanmamıştır. Puanlar, sonsuz bir uğraşın aracı olabilirken seviyeler sınırlı bir zaman diliminde gerçekleşen ve sonlu eylemlere işaret etmektedir. 


\subsubsection{Rekabeti Tetikleyen Bir Mekanik Olarak Lider Tablosu}

PLB üçlemesinin diğer bir unsuru olan lider tablosunun kullanımı da incelenen uygulamalar arasında farklılaşmaktadır. Buna göre, sadece miCoach ve Swarm'da lider tablosu kullanılmaktadır. Her iki uygulamada da lider tablosunun kullanım amacının kullanıcılar arasında rekabetin yaratılması olduğu gözlenmektedir. Örneğin, miCoach'da "adiRunner85" adlı kullanıcı grup arkadaşlarını yaraşmaya davet ederken, tartışma konusunun başlığını "lider tablosu rekabeti" olarak yazmakta ve kullanıcilar arasında lider tablosunda en üst sirada yer alacakları ödüllendireceklerini belirtmektedir.

Benzer şekilde Swarm'ın blog sayfasında lider tablosunun özellikle kullanıcılar arasında rekabeti yaygınlaştırmayı amaçladığı belirtilmektedir. Swam, ilk yayınlandığında lider tablosuna yer vermemiş ancak talepler doğrultusunda lider tablosu, daha sonra Swarm'a eklenmiştir. Kullanıcılar lider tablosunda en üst sırada yer alarak "Mayor" olmak için mücadele etmektedir. Swarm, rekabet olgusunu lider tablosu dışında bir de etiketler adı altında geliştirdiği rozetler için de uygulamaktadır. Yine blog sayfasında belirtildiği üzere; kullanıcıların kendi aralarında en fazla etikete sahip olan olmak için mücadele ettikleri söylenmektedir.

Lider tablosu, Khan Academy ve SuperBetter'da kullanılmamaktadır. Bunun nedeni; grup ilişkilerin çok alt düzeyde olması, mücadele biçimlerinin kişi ve sistem arasında yaşanması olduğu düşünülmektedir. Özellikle SuperBetter, teması gereği herhangi bir rekabetin oluşmasını gerektirecek bir yapıya sahip değildir. Burada kullanıcılar kişisel gelişimleri için faaliyetlerde bulunmaktadır ve bu nedenle kullanıcılar arasında rekabeti yaşatacak mekaniklere de rastlanmamaktadır.

Khan Academy de benzer şekilde eğitim temelli bir uygulama olup, bir sinıf ortamını oluşturmadığı gibi; bireysel olarak yetenekleri geliștirmeye dönük bir temaya sahiptir. Bu nedenle burada da bir lider tablosuna ihtiyaç duyulmadığı gözlenmektedir. Ancak özellikle kullanıcılar tarafından yoğun olarak lider tablosunun siteye eklenmesi talep edilmektedir. Bu yönde sitenin tartışma bölümünde birçok konu açılmış ve site yöneticilerinden lider tablosunun uygulamaya entegre edilmesi talep edilmektedir. Hatta site yönetimi bu konuda adım atmadığı için, bazı kullanıcılar siteden bağımsız olarak en yüksek enerji puanlarına sahip kullanıcılardan oluşan bir lider tablosunu siteden bağımsız bir alanda oluşturmuşlardır ve bunu her ay güncellemektedirler.

Khan Academy'de bazı kullanıcılar, özellikle diğer kullanıcılar ile aralarında nasıl bir puan farkı olduğunu görmek veya sıralamalarını bilmek için lider tablosu talep etmektedirler. $\mathrm{Bu}$ anlamda "Xepher" adlı kullanıcı, diğer kullanıcılar ile kendisi arasındaki puan farklarını bilmenin eğlenceli olacağını belirtmektedir. Xepher'in bu teklifi bazı kullanıcılar tarafindan beğenilirken, bazıları da Khan Academy'nin bir eğitim sitesi olduğunu ve lider tablosunun insanların öğrenimine yardımcı olmayacağını savunmaktadır. Başka bir kullanıcı ise insanların puanlarının onlardan habersiz lider tablosunda yer almasının gizliliğinin ihlali olduğunu vurgulamaktadır.

\subsubsection{Başarıların sembolleştirilmesi}

Tablo 3' de göze çarpan diğer bir unsur ise tüm uygulamalarda rozetler veya başarıyı gösteren sembollerin kullanılmasıdır. PLB üçlemesinin son halkası olan rozetler başarının gösterilmesinde en önemli oyun elemanlarıdır (Werbach ve Hunter, 2012: 70). İncelenen uygulamalarda da bu yönde bir kullanımı olduğu gözlenmektedir. Tüm uygulamalar, kullanıcıların başarılarını belirli sembollerle ile gösteren mekaniklere sahiptir. Rozetlerin tasarımı sitenin hedef kitlesine ve içerikle doğrudan ilişkili olmaktadır. Örneğin, miCoach'da rozetler doğrudan sporcunun yaptığ 1 aktivitenin sembolleştirmesi ile ilgilidir; kullanıcının ne kadar kalori tükettiği, ne kadar mesafe koştuğu gibi; yaptığ 1 spordaki başarıları görselleştiren unsurlardır.

Buna karşın Khan Academy'de rozetler ilk bakışta doğrudan içerikler alakalı görünmemektedir. Rozetler, samanyolu galaksisi teması esas alınarak tasarlanmış olup; "ay", "güneş" gibi isimlerle kategorilere ayrılmaktadır. Bu anlamda Khan Academy'de rozetlerin 
tasarımı diğer üç uygulamadan farklılaşmaktadır. Rozetlerin bu şekilde tasarlanması aynı zamanda onların etrafında dedikoduların, hikayelerin oluşmasını ve bunların toplanması için daha fazla mücadele edilmesini teşvik etmektedir.

Rozetlerin motive edici yönü, büyük ölçüde koleksiyonlar ile ilgili olmaktadır. $\mathrm{Bu}$ açıdan Tablo 3'e bakıldığında tüm uygulamalarda aynı zamanda koleksiyonların da yer aldığı görülmektedir. Özellikle Khan Academy'de tüm rozetlerin toplanması için büyük bir mücadele verildiği bu konuda yapılan tartışmalardan anlaşılmaktadır. Site içinde tartışma ortamlarında kullanıcılar sıklıkla bu rozetlerin nasıl elde edileceğine yönelik sorular sormaktadır. Örneğin en büyük rozet olan "kara delik" gizemli bir hedefe dönüşmüş olup, kullanıcıların birçoğu buna nasıl ulaşılacağına dair sorular sormaktadır.

Anonim bir isimle tartışma başlatan bir kullanıcı, site yöneticilerinden bu rozetin nasıl elde edileceğini artık açıklamalarını isterken, "Raghav" adlı kullanıcı ise "Kara delik ismi oldukça eğlenceli ancak bunu biz kazanamıyoruz. Çok çalıştığımızı göstermesi açısından bunu kazanabileceğimizin gösterilmesi çok iyi olurdu." demektedir.

Koleksiyonlar, aynı zamanda bir kullanıcının ne kadar başarılı olduğunun da göstergesidir. $\mathrm{Bu}$ yüzden birçok kullanıcı incelenen dört uygulamada da daha fazla rozet toplamaya çalışmaktadırlar. Koleksiyonların varlığı bireylerin bu koleksiyonların gerektirdiği rozetleri toplamaya teşvik etmektedir. Bu nedenle sıklıkla bunların nasıl kazanılacağına dair sorular sormaktadırlar. Örneğin Swarm kullanıcıları aşağıdaki gibi bilgiler talep etmektedirler.

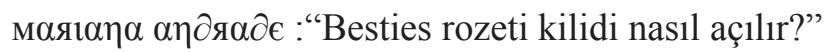

Jeffrey Depp: Lütfen "limited time" ve "here tos tay" etiketlerini programa ekleyin. Neden çıkardınız onları?! Bunlar da yeni rozetler olabilir!"

Assyl Tobakabulov: ‘Lütfen rozetleri geri getirin! Sadece bir dilek! (Foursquare rozet sisteminden söz etmektedir.)

Bunların yanı sıra Swarm yöneticileri bir etiket fotoğrafı paylaştı̆̆ında birçok kullanıcı aynı soruyu sormakta; "Bunu nasıl elde ederim?" Bu anlamda rozetlerin uygulama içinde kullanıcıların daha fazla faaliyet göstermeleri için motive edici bir etkiye sahip olduğu görülmektedir.

\subsubsection{Kullanıcılara kendi karakterlerini yaratma firsatı verilmesi}

Tablo 3'de görüleceği üzere Khan Academy, miCoach ve Swarm'da kullanıcılara uygulamayı kişileştirme ve kendilerine göre belirli konularda tasarlama imkanı tanınmaktadır. Araştırma bulgularının ortaya koyduğu üzere, uygulamalar iki biçimde kullanıcılara uygulamayı kişileştirme imkanı vermektedir. Birincisi, profil olarak adlandırılan ve kullanıcıların fotoğraf, takma isim ve kısa kişisel bilgilerini yazabildikleri sayfalardır. İkincisi ise oyun dünyasında sıklıkla başvurulan ve oyuncuya düşlediği karakteri seçme imkanı veren avatarlardır.

Tablo 3'e baktığımızda sadece SuperBetter'da kişileştirmenin olmadığı anlaşılmaktadır. Bunun yanı sıra profiller dışında avatar kullanan tek uygulama, Khan Academy olarak görülmektedir. Profil kullanımı kullanıcılara uygulama üzerinde kendilerine göre bir tasarım yaratmada kısmen yardımcı olmasına rağmen, oyuncuların karakterlerini yansıtan mekanikler temelde avatarlardır. Oyunun "sihirli çemberi" içinde avatarlar oyuncuya gerçek dünyadan kopmasına ve sanal dünyada kendine ait bir kişilik yaratmasına yardımcı olmaktadır. Bu nedenle avatarların kullanımı, oyunlaştırma uygulamasını oyun sistemine daha fazla yakınlaştırmaktadır.

\subsubsection{Uygulamalar arasında diğer ortak özellikler ve farklılıklar}

İncelenen dört örnek olayın tamamında kullanıcıların aktivitelerini çevresiyle paylaşabileceği bir mekaniğe rastlanmıştır. Uygulamalar, kullanıcılara faaliyetlerini paylaşmalarını teşvik ederken, yeni kullanıcıların da uygulamadan haberdar olmasını sağlamaktadırlar. Bunun yanı sıra, uygulamada arkadaşlarını davet etmelerini veya uygulamaya eklemlerini de önermektedirler. Bu anlamda paylaşım noktaları hem uygulamanın tanıtımının yapılmasına hem de kullanıcının çevresiyle başarılarını paylaşmalarını sağlamaktadır. 
Aynı zamanda dört uygulamada da tartışma ortamını sağlayacak mekaniklerinin olduğu görülmüştür. Bunun nedeni uygulamaların tamamen bir oyun olmasından ziyade bir oyunlaştırma olmasından kaynaklanmaktadır. Genelde çok az oyunda kullanıcılara belirli konularda tartışma yapma imkânı tanınmaktadır. Ancak oyunlaştırmalar, kullanıcıya sadece eğlenceli bir deneyim yaşatmanın ötesinde içeriklere bağlı olarak oyun-dışı hedeflere de sahiptir. İncelenen çalışmalardan örnek vermek gerekirse; miCoach kullanıcılara sportif yeteneklerini geliştirmeye yardımcı olurken, SuperBetter kullanıcıları esenliğe kavuşturmayı amaçlamaktadır. Uygulamalar, kullanıcılar arasında işbirliğini artırarak, deneyimlerini paylaşmalarına ve bu şekilde bir topluluk kültürünün de oluşmasını sağlamaktadır.

Uygulamalar arasında diğer bir ortak mekanik ise bildirimlerdir. Oyunların en önemli özelliklerinden biri de hızlı geribildirim yapmasıdır (Paharia, 2013). Oyunlaştırmada kullanılan mekaniklerin tamamı esasında bir geribildirim işlevi görmektedir (Marczewski, 2013). Ancak özellikle kullanıcılara yaptıkları faaliyetler hakkında anında ya da toplu halde geribildirim sunan mekanikler bulunmaktadır. İncelenen dört uygulamada da bu şekilde çalışan mekanikler tespit edilmiştir. Bildirimler, kullanıcılara faaliyetlerini takip etmelerini, daha fazla uygulamaya katılım göstermelerini sağlamaktadır. Bu nedenle bazı kullanıcıların bu mekaniklerin daha fazla kişileştirilmesini de talep ettikleri görülmüştür. Örneğin bir Khan Academy kullanıcısı olan "Balaji Panneer Saravanan" diğer kullanıcılara tartışma ortamlarında yardımcı olmak için eğitim gördüğü konuları bitirdiğinde bu konuda soru sorulduğunda kendisine de bildirilmesini talep etmektedir. miCoach kullanıcıs "mastair" ise e-posta adresine yaptığı aktiviteler ile ilgili bildirim yollanmasını istemektedir.

Ancak bazı kullanıcıların da bildirimler mekaniğini devre dışı bırakmak istedikleri görülmektedir. Bildirimlerin aşırı gönderilmesi kullanıcıları bıktırmakta ve yaptıkları faaliyetlere odaklanmalarını engellediği görülmektedir.

\section{Sonuç ve Değerlendirme}

Oyun literatüründe oyunların temelini teşkil eden üç mekanikten söz edilmektedir; puanlar, rozetler ve lider tablosu. Birçok oyunlaştırma uygulaması bu üç yapı üzerine kuruludur ve bunların yerleştirilmesi ile bir içeriğin oyunlaştırma sürecinin büyük ölçüde sonuçlanacağı varsayılır. Çünkü puanlar kullanıcılara bir şeyleri kazandıkları hissini, rozetler bu kazançların görselleştirilmesini ve lider tablosu da kullanıcılar arasında rekabeti ortaya çıkarmaktadır. Bunların bir içeriğin oyun-benzer kılınması için yeterli olduğu düşünülür (Chou, 2015, 13-20). İncelenen uygulamalar içinde lider tablosu hariç puanlar ve rozetlerin dört uygulamada da olduğu gözlenmiş̧tir. Lider tablosunun olmayışı uygulamaların içeriği ile ilgili olup, kullanıcılar arasında rekabetin yaratılmasının yararlı olup olmayacağı ile ilgili verilen bir karardır. Çünkü her lider tablosu kullanıcıları daha fazla oynamaya teşvik etmemekte ve bazen de kullanıcıların motivasyonlarını düşürebilmektedir (Werbach ve Hunter, 2012, 76). Bu yüzden Khan Academy'de kullanıcılar, lider tablosu istemelerine rağmen, uygulama yöneticileri eğitim sürecinde başarılı olmayacağ düşünülerek lider tablosu eklemeyi reddetmiştir.

Benzer şekilde tüm uygulamalarda bildirimlere rastlanmaktadır. Esasında her mekanik bir geribildirim işlevi görmektedir (Marczewski, 2013). Ancak uygulamaların birçok aşamasında özellikle bildirim işlevi gösteren mekanikler gözlemlenmiştir. Bunlar, kullanıcıları yaptıkları faaliyetlerin izini süren ve gerekli aşamalardan nasıl geçtiğini gösteren, kullanıcıyı sürekli aktif kılmak için uyaran mekaniklerdir. Tüm uygulamalarda göze çarpan diğer bir mekanik olan sosyal paylaşım noktaları ise, sosyal ağların yaygınlaşmasının bir sonucu olduğu öngörülmektedir. Bu ağlar sayesinde kullanıcı hem kendi hem de uygulamanın tanıtımını yapmaktadır.

Bunların yanı sıra literatürde yer almayan ancak örnek uygulamaların incelenmesinde bazı mekanikler tespit edilmiştir. Hedefler, gösterge tablosu, tartışma ortamları ve ayarlar olarak tanımlanan bu mekanikler, daha önceki çalışmalarda belirtilmemesine rağmen bu uygulamalarda mevcut olduğu tespit edilmiştir. 
Araştırmanın yöneldiği sorulardan birisi de, oyun mekaniklerinin uygulamalarda nasıl kullanıldığı yönündeydi. Oyun mekaniklerinin nicel varlığı uygulamalarda benzer oranlarda olmasına rağmen, kullanım biçimi uygulamalar arasında değişiklik göstermektedir. Bu farklılı̆̆ın en önemli nedeni; uygulamaların içeriği ve amaçlarından kaynaklanmaktadır. Oyun elemanlarının seçilmesinde ve tasarımında uygulama amaçlarını destekleyecek biçimde tasarlandığı görülmektedir. Örneğin, tüm uygulamalarda rozetler kullanılmasına rağmen, bunların nasıl kazanılacağı uygulamaların kullanıcıya yönelik hedeflerine bağlı olarak değişmektedir. miCoach'da belirli bir mesafenin koşulması üzerine verilirken, SuperBteer'da bunlar görevlerin başarılmasına bağlı olarak verilmektedir.

Sonuç olarak, bu çalışmanın temel sorusunu teşkil eden oyun elemanlarının oyunlaştırma uygulamalarında gözlenmesi ve açıklanması, oyun mekanikleri özelinde gerçekleştirilmiştir. Araştırmada bulguların genellemesinden ziyade olguyu derinlemesine kavrama amacı taşıdığ için, oyun elemanları detaylı açıklamaya çalışılmıştır. Bu sayede benzer çalışmalar ile ileride oyun elemanlarının kuramsal çerçevesinin oluşturmasına katkı sunacağa umulmaktadır. Bunun yanı sıra oyun elemanlarının neler olduğu, kategorileri ve nasıl işlediği ile ilgili bir çerçevenin oluşturulması oyunlaştırma tasarımına da yardımcı olacağ1 öngörülmektedir. "Takım çantası (Werbach ve Hunter, 2012)" olarak ifade edilen oyun elemanları ile bir kuramsal çerçevenin oluşturulması ve uygulayıcılar için oyunlaştırma uygulamalarının tasarlanmasında amaçlarına göre oyun elemanları seçme konusunda bir rehber niteliği taşıyacağı düşünülmektedir. 


\section{Kaynakça}

Adams, E. ve Dormans, J. (2012). Game Mechanics: Advanced Game Design. Berkeley, Calif, ABD: New Riders.

Blohm, I. ve Leimeister, J. Marco (2013). Gamification. Business \& Information Systems Engineering, 5(4), 275-278.

Bunchball. Gamification 101: An Introduction to Game Dynamics. Erişim: 15 Kasım 2015. http:// go.bunchball.com/rs/bunchball/images/Bunchball_Gamification_101_0912.pdf,

Chou, Y.-K. (2015). Actionable Gamification: Beyond Points Badges Lederboards. ABD: Octalysis Media.

Deterding, S., Sicart, M., Nacke, L., O’Hara, K. ve Dixon, D. (2011). Gamification. Using Gamedesign Elements in Non-gaming Contexts. D. Tan (Ed.). CHI'11 Extended Abstracts on Human Factors in Computing Systems (s.2425-2428) New York, ABD: ACM.

Deterding, S. (2012). Gamification: Designing for Motivation. Interactions, 19 (4), 14.

Dul, J. ve Hak, T. (2008). Case Study Methodology in Business Research. Amsterdam, Boston: Elsevier/Butterworth-Heinemann/Elsevier.

Evans, D. ve McKee, J. (2010). Social Media Marketing: The Next Generation of Business Engagement. Indianapolis, Ind.: Wiley.

Ferah, A. B. (2015). Foursquare'in ve Swarm'in Türkiye'ye ait verileri [infografik]. Erişim: 21 Nisan 2016. http://sosyalmedya.co/foursquarein-ve-swarmin-turkiyeye-ait-verileriinfografik/

Flatla, D. R., Gutwin, C., Nacke, L. E., Bateman, S. ve Mandryk, R. L. (2011). Calibration Games. J. Pierce, M. Agrawala ve S. Klemmer (Ed.). the 24th annual ACM symposium: 16-19 Ekim 2011(s.403). Santa Barbara, CA, ABD.

Foxman, M. (2014). Rethinking gamification (Ed: M. Fuchs, vd.). How to Win Foursquare: Body and Space in A Gamified World (s. 71-90). Lüneburg, Germany: Hybrid Publishing Lab.

Gosling, V. K. ve Crawford, G. (2011). Game Scenes: Theorizing Digital Game Audiences. Games and Culture, 6(2), 135-154.

Hamari, J. (2015). Do Badges Increase User Activity?: A Field Experiment on The Effects of Gamification. Computers in Human Behavior, 71, 469-478.

Hamari, J. ve Koivisto, J. (2015). Why Do People Use Gamification Services? International Journal of Information Management, 35(4), 419-431.

Herger, M. (2014). Enterprise Gamification: Engaging People by Letting Them Have. CreateSpace Independent Publishing Platform.

Huizinga, J. (2006). Homo Ludens: Oyunun Toplumsal İşlevi Üzerine Bir Deneme. İstanbul: Ayrint1.

Hunicke, R., LeBlanc, M. ve Zubek, R. (2004). MDA: A Formal Approach To Game Design And Game Research. AAAI Workshop on Challenges in Game AI, 1722.

Huotari, K. ve Hamari, J. (2012). Defining Gamification: A Service Marketing Perspective. A. Lugmayr (Ed.). Proceeding of the 16th International Academic MindTrek Conference: 03-05 Ekim 2012 (s.17-22). Tampere, Finlandiya. 
Kapp, K. M. (2014). The Gamification of Learning and Instruction Fieldbook: Ideas into Practice. San Francisco, CA, ABD: Wiley.

Knaus, M. (2015). Persuasive Technologies and Applications in Health and Fitness. Persuasive Technologies and Applications. 3(2), 5-11.

Liu, Y., Alexandrova, T. ve Nakajima, T. (2011). Gamifying Intelligent Environments. A. A. N. Shirehjini, H. S. Albayrak ve A. Yassine (Ed.). Ubi-MUI '11: Proceedings of the 2011 international ACM Workshop on Ubiquitous Meta User Interfaces: Kasim 2011 (s.712). Arizona: $A B D$.

Marczewski, A. (2013). Gamification: A Simple Introduction \& A Bit More. self-published on Amazon Digital Services, 2013. Kindle edition, Loc 1405.

Mcdaniel, R., R. Lindgren ve J. Friskics (2012). Using Badges for Shaping Interactions in Online Learning Environments. Professional Communication Conference (IPCC), 2012 IEEE International:08 - 10 Ekim 2012 (s.4-5). University of Central Florida, Orlando, FL, ABD.

McGonigal, J. 2010 (TED2010). Gaming Can Make A Better World. Erişim: 04 Nisan 2016. http://www.ted.com/talks/jane_mcgonigal_gaming_can_make_a_better_world

Merino de Paz, Blanca (2013). Gamification: A Tool to Improve Sustainability, Oxford. Erişim:15.12.2015 http://studentnet.cs.manchester.ac.uk/resources/library/thesis abstracts/MSc13/FullText/MerinoDePaz-Blanca-fulltext.pdf.

Paharia, R. (2013). Loyalty 3.0: How Big Data and Gamification are Revolutionizing Customer and Employee Engagement, ABD: McGraw-Hill Education.

Robinson, D. ve Bellotti, V. (2013). A Preliminary Taxonomy of Gamification Elements for Varying Anticipated Commitment. Workshop on Designing Gamification: Creating Gameful and Playful Experiences: 27 Nisan - 2 Mayss 2013, Paris, Fransa.

Ryan, R. M.; Rigby, C. Scott ve Przybylski, A. (2006). The Motivational Pull of Video Games: A Self-Determination Theory Approach. Motivation and Emotion, 30(4), 344-360.

Santhanam, R. ve Liu, D. (2015). Towards Meaningful Engagement: Gamification Designs for Gameful Interaction with Information Systems. SSRN Electronic Journal, 8(2), 128140 .

Schell, J. (2014). The Art of Game Design: A Book of Lenses. Hoboken, ABD: Taylor and Francis.

Sever, N. S., Koçak, G. N., \& Kuhzady, S. (2015). The Evaluation of Potentials of Gamification in Tourism Marketing Communication. International Journal of Academic Research in Business and Social Sciences, 10(5), 188-202.

Smith C. (2016). 20 Important Stats and Facts About Foursquare. Erişim: 04 Nisan 2016. http:// expandedramblings.com/index.php/by-the-numbers-interesting-foursquare-user-stats/

Suh, A., Wagner C. ve Liu L. (2015). The Effects of Game Dynamics on User Engagement in Gamified Systems. System Sciences (HICSS), 2015 48th Hawaii International Conference:5-8 Temmuz 2015. Hawaii, ABD.

Şimşek, H. ve Yıldırım, A. (2013). Sosyal Bilimlerde Nitel Araştırma Yöntemleri. Ankara: Seçkin Yayıncılık.

Thompson, C. (2011). How Khan Academy is Changing The Rules of Education. Wired Magazine, 126, 1-5. 
Terlutter, R. ve Capella, M. L. (2013). The Gamification of Advertising: Analysis and Research Directions of In-Game Advertising, Advergames, and Advertising in Social Network Games. Journal of Advertising, 42(2-3), 95-112.

Werbach, K. (2014). Persuasive Technology. D. Hutchison, T. Kanade, J. Kittler, J. M. Kleinberg, A. Kobsa ve F. Mattern, ve diğerleri (Ed.). (Re)Defining Gamification: A Process Approach (s. 266-272). Cham: Springer International Publishing.

Werbach, K. ve Hunter, D. (2012). For The Win: How Game Thinking Can Revolutionize Your Business. Philadelphia, ABD: Wharton Digital Press.

Yamagiwa, S.; Ohshima, H. ve Shirakawa, K. (2015). Development of Skill Scoring System for Ski and Snowboard. J. Cabri (Ed.) Sports science research and technology support. Rome, Italy, October 24-26, 2014. Cham: Springer. ss. 1-15.

Yin, R. K. (2003). Case Study Research: Design and Methods. Thousand Oaks, Calif., ABD: Sage Publications.

Zichermann, G. ve Cunningham, C. (2011). Gamification by Design: Implementing Game Mechanics in Web and Mobile Apps, California, ABD: O'Reilly.

Zichermann, G. ve Linder, J. (2010). Game-Based Marketing: Inspire Customer Loyalty Through Rewards, Challenges, and Contests. Hoboken, N.J., ABD: Wiley. 